\title{
More than 40 million years of oblique subduction recorded in the magmatism of the westernmost Aleutian arc
}

\author{
T.W. HÖFIG ${ }^{1 *}$, M. PORTNYAGIN ${ }^{2}$, K. HOERNLE ${ }^{2}$, F. \\ HAUFF $^{2}$, B.R. JICHA ${ }^{3}$, J-A. WARTHO ${ }^{2}$, P. VAN DEN \\ BOGAARD $^{2}$, D. GARBE-SCHÖNBERG ${ }^{4}$ \\ ${ }^{1}$ Texas A\&M University, College Station, TX, USA \\ (*hoefig@iodp.tamu.edu) \\ ${ }^{2}$ GEOMAR Helmholtz Centre for Ocean Research Kiel, \\ Germany \\ ${ }^{3}$ University of Wisconsin-Madison, Madison, WI, USA \\ ${ }^{4}$ Christian Albrechts University Kiel, Germany
}

The $\sim 2,200 \mathrm{~km}$ long Aleutian subduction zone forms the northern boundary of the Pacific plate, and establishes the Aleutian arc as the key region, which recorded the history of the Bering Sea and northern Pacific. However, the plate tectonic reconstructions have remained uncertain due to significant gaps in the geochemical and geochronological record of the Aleutian arc. Here we report new ${ }^{40} \mathrm{Ar} /{ }^{39} \mathrm{Ar}$ age, major and trace element, and $\mathrm{Sr}-\mathrm{Nd}-\mathrm{Pb}$ isotopic data for magmatic rocks from Komandorsky (Bering and Medny) Islands in the westernmost part of the Aleutian arc.

Early Eocene calc-alkaline and tholeiitc mafic series on Medny Island demonstrate the oldest known volcanic activity that protracted over 20 million years (52-31 Ma). A tholeiitic felsic series formed almost synchronously on Medny Island at 48-22 Ma. This bimodal volcanism shows a slab fluiddominated trace element signature. Magmatic activity on Bering Island is initially marked by calc-alkaline basaltic andesite lava flows (36-33 Ma) with a moderate garnet signature, indicating the onset of partial slab melting. This process intensified over time, leading to extensive adakitic mafic to intermediate volcanism on Bering Island that peaked at 23-20 Ma. Lastly, adakitic dikes and intrusives intruded at 14-10 Ma on Medny Island. Magmatism on the islands then ceased when the present-day strike-slip setting took over.

The $\mathrm{Sr}-\mathrm{Nd}-\mathrm{Pb}$ isotopic signature of westernmost Aleutian magmatism changes systematically with decreasing age. For instance, a continuously declining ${ }^{207} \mathrm{~Pb} /{ }^{204} \mathrm{~Pb}$ ratio suggests waning sediment input into the subduction zone. Remarkably, the temporal Komandorsky isotopic trends mimic the modern along-strike isotopic changes from east to west. This suggests that the Komandorsky block once resided $\sim 1,000 \mathrm{~km}$ to the east of its present location and has continously been transported westward due to an increasingly oblique subduction accompanied by a gradually growing strike-slip component since the very beginning of magmatism. 